\title{
English learners' voices on integrating poetry through a transactional approach in an EFL classroom*
}

\author{
Luis Fernando Gómez Rodríguez ${ }^{* *}$
}

\begin{abstract}
This case study examined how a group of EFL learners at a University in Colombia were encouraged to read and discuss several American poems for the first time in their lives through the reading transactional approach. Participants' reading experience and critical reactions to poetry constituted the core data that were collected through field notes, learners' artifacts (written essays), and one questionnaire. Data were analyzed through grounded approach and content analysis. Findings revealed that learners first focused on vocabulary and language structures and then on meaning. This research concluded that the incorporation of poetry as content in EFL education can help learners improve their communicative competence and critical reading skills.
\end{abstract}

Keywords: Transactional theory, EFL learners, Efferent stance, Aesthetic stance, Poetry in EFL.

\section{Las voces de los estudiantes sobre la inclusión de la poesía en una clase de inglés a través de un enfoque transaccional}

\section{Resumen}

Este estudio de caso describe cómo un grupo de estudiantes de inglés de una Universidad de Colombia leyeron y discutieron varios poemas de la literatura estadounidense por primera vez en sus vidas mediante el enfoque de lectura transaccional. Las reacciones críticas de los participantes sobre los poemas constituyeron los datos esenciales que se recogieron a través de notas de campo, artefactos (ensayos escritos) y un cuestionario. La información recogida se analizó con el enfoque fundamentado en los datos y con el enfoque de análisis de contenido. Los hallazgos revelan que los aprendices se enfocaron primero en entender las estructuras lingüísticas y luego en construir significado. Se concluye que la incorporación de la poesía como contenido en la enseñanza del inglés puede ayudar a que los estudiantes mejoren su competencia comunicativa y su lectura crítica.

Palabras clave: Teoría de la transacción, estudiantes de inglés, nivel eferente, nivel estético, la poesía en la enseñanza del inglés.

Recibido: 09/05/17

Aceptado: 24/03/18

This article is the result of an independent research work entitled "The Inclusion of poetry in an EFL classroom", conducted in the Language Department at Universidad Pedagógica Nacional de Colombia in 2016. It was sponsored by the researcher's own resources. The researcher is grateful with the Language Department and the students that participated in this study.

Colombian. Holds a Ph.D. in English Studies from Illinois State University, USA and a M. A. in education from Carthage College, USA. He currently teaches North American literature at Universidad Pedagógica Nacional de Colombia. Bogota, Colombia. lfgomez@pedagogica.edu.co 


\section{Introduction}

The inclusion of literature in the English as a Foreign Language (EFL) classroom is not a new teaching practice. However, Mckay (1982), Paran (2006), and Khatib (2011) report that its integration in language teaching has been reduced dramatically because many instructors think that literary language (poetry, short stories, novels, and drama) is difficult material for learners, has no practical value in normal communication, and lacks appropriate methods to be taught. In regards to the inclusion of poetry, in particular, research is not only scarce (Hanauer, 2010), but there is a widespread perception among teachers that it is not a suitable resource in language instruction because of its sophisticated language, complex linguistic structures, and deviation from the linguistic norm (Widdowson, 1984; Lazar, 1993; Buckledee, 2002; Khansir, 2012). In fact, poetry deviatesfrom the rules of language because it constitutes an artistic combination of poetical figures of speech (similes, metaphors, alliteration, and imagery, among many other features) that produce indirect meanings which need to be inferred. There fore, poetry seems to cause confusion and even frustration among EFL teachers and learners.

In addition to these perceptions, the groundbreaking growth of communicative trends in language learning during the last forty years, such as task-based approach and content-based approach, have emphasized the development of learners' communicative competence: The speakers' knowledge and skills to understand, produce, and negotiate meaning in situations of everyday life. It is an ability to function in real communicative and dynamic exchanges with other interlocutors (Canale, 1983; Richards and Rodgers, 2001; Savignon, 1972; 2001). This, in English classes, learners are mainly asked to speak about their own personal interests and experiences; and are invited to simulate situations that they would encounter in every day life because effective communication for practical purposes and social interaction with other people is the main goal (Richards \& Rodgers, 2001). Because of this communicative emphasis, literary texts have been disregarded in the EFL classroom, since many teachers claim that poetry seems not to meet the goals of language for immediate social purposes. These perceptions have caused that many EFL learners in several countries receive a University Language Degree without having read any literary texts because these materials are not incorporated in the syllabi of many Foreign Language Programs (Qiping \& Shubo, 2002). 
Another limiting factor is that published research on the use of literature in EFL has mostly been based on authors' hypothetical assertions and theoretical teaching suggestions (Hanauer, 2001; Bernhardt, 2001).There is an urgent need, then, to do more empirical research (Maley, 2001; Paran, 2006), and, as Clapsadle (2014) suggests, publish "in-depth research on the process of literary reading" (p. 5) in the foreign/second language classroom, including research on the teaching of poetry (Panavelil, 2011).

EFL education in Colombia has not been the exception to this reality. Research on the inclusion of poetry is unusual because most Colombian teachers tend to focus on developing language competence through communicative text books and grammar books that gradually present linguistic forms and communicative functions in an orderly fashion. Teachers also use Internet sources, language learning websites, music videos, movies, and abridged editions of short stories as chief instructional materials. Although they are suitable sources to learn the foreign language, it is a disadvantage that, at least, during the last ten years, published research on the use of poetry in foreign language teachingis absent in major Colombian ELT journals.

Despite the limited use of poetry in Colombia, as it happens in many EFL contexts worldwide, new theoretical arguments support its use as a means to enhance English language proficiency (Khatib, 2011). That is why this article reportson how a group of EFL learners responded to the inclusion of poetry in the language classroom. Participants' directvoices and opinions on reading poetry constituted the main data gathered and analyzed, and determined the usefulness of this literary genre in this particular setting. Ultimately, this kind of studies is needed so that the EFL community can start considering the contributions of poetry in the foreign language classroom.

\section{Theoretical framework}

\subsection{The inclusion of poetry in EFL education}

Kramsch (1993) suggests that EFL learners should be exposed to literary language because it offers great opportunities to construct meaning and enhance language competence in a more genuine way. Literature is real language in use, which contrasts the arranged presentation of language items regularly taught in traditional classes (Brumfit \& Carter, 1986). For 
Starz (1995), "Poetry is another way of communicating" (p. 3) that motivates students to use the four language skills as learners can listen to, read, speak, and write about the images, meaning, and themes presented in the poems by trying to reach possible interpretations. Likewise, poetry enables learners to build vocabulary in significant contexts (Lazar, 1993; Kellem, 2009). According to these authors, poetry is a salient means that can help learners improve language proficiency because they cannot only make sense out of poetical language and negotiate meaning, but can also be involved in thought-provoking and communicative experiences in the foreign language.

Additionally, poetry deals with universal topics to people of all nations, including the meaning of life, love, and nature, the mystery of death and God, as well as the diversity of human feelings, values, and dilemmas. Maley and Duff (1989) recognize the universality and non-triviality of the themes in poetry while Kramsch (1993) sees poetry as deep in thought that invites readers to acquire knowledge about human "values, [...] collective imaginings and historical frames of reference that constitute the memory of a speech community" (p. 175). Learners make profound reflections about human life, the world, and personal experiences when they are encouraged to read between the lines and construct meaning from what they read. This idea relates to Hanauer's (2012) view of the role of language learning in ESL/EFL: To facilitate "personally meaningful expression" and emphasize the "presence of the living, historically situated, individual human being at the center of the language learning process" (106). For Kramsch (1993) and Hanauer (2012), the purpose of learning a foreign language is not only linguistic, communicative, and cognitive. "It involves the whole human being beyond just intellectual abilities" (Kramsch, 1993, p. 105), including his/her emotions, personal concerns, and human experiences. Such humanized dimension should be fostered through poetry in EFL learning, as English teachers are educating learners to become more humanitarian, intercultural, and world citizens in the process of globalization.

Poetry also has advantages in the real world as it can be seen as a naturalistic reading task (Hanauer, 2001) that can prepare EFL learners to deal with figurative language (metaphors, allusions, and similes) in daily communication, since we do not speak in direct and literal ways all the time (Conway, 2015). Many of the messages that we receive or produce contain metaphorical/figurative language, as can be seen in 
journalistic language (E.g. Star Treck TV series breeds a cult of space worshippers), advertisement (Coca-cola opens happiness), and popular songs. For Hanauer (2001), poetry represents a naturalistic reading task that is part of the many real-world language types, such as the lyrics of popular songs.

Poetry ambiguity is another powerful feature that allows learners to come up with multiple interpretations and attempt to agree on its messages and themes from different perspectives. Thus, literary ambiguity generates language competence development, meaning negotiation, and even debate, as learners have to defend their interpretations with coherent arguments (Maley \& Duff, 1989; Kramsch, 1993; Khansir, 2012; Sakamoto, 2015). This relates to the fact that poetry contributes to critical reading and argumentation in EFL education (Hismanoglu, 2005 cited by Khansir, 2012) as learners are engaged in understanding and interpreting messages mentally and rationally.It "fosters reflection and a critical stance vis-à-vis one's one and the foreign meanings" (Kramsch,1993,175), chief aspects comprised by transactional reading.

\subsection{The transactional approach to literature}

The transactional approach is a teaching literary theory proposed by Rosenblatt (2002) who states that meaning does not reside in the literary text, but emerges through the reciprocal relationship between the reader and the text. Reading a poem and any other literary text involves a "transaction" in which the reader is stimulated by the text to create meaning and the text acquires its meanings when the reader brings his/her personal feelings, knowledge, and experiences to the reading. Rosenblatt claims that each reader is capable of finding personal interpretations that could differ from those of the author and those of other readers, depending on personal and academic experiences, contextual factors, and sociocultural backgrounds.

Understanding and interpreting texts demands two kinds of stances called the efferent reading and the aesthetic reading (Rosenblatt, 1995; 2002). The former refers to the act of reading a literary text in order to get information and gain meaning out of it. At this level, readers produce responses by focusing on implicit meaning based on rational interpretations. Although various interpretations may arise during the efferent transaction, they are only valid with evidence and convincing arguments (Probst, 1988). 
Aesthetic reading, on the other hand, embraces the literary pleasure that the reader experiences during the transactional process. Meaning is also possible when the reader responds emotionally to literary language. Rosenblatt (1995) states, "any literary work gains its significance from the way in which the minds and emotions of particular readers respond to the verbal stimuli offered by the text" as the reader discovers that literature "arises a sense of organized structure of perceptions and feelings which constitutes for him the aesthetic experience" (p. 28). Consequently, the reader may trigger feelings of joy, pleasure, sadness, or fear through the words, images, the tone, and topics in a poem.

Rosenblatt (1995) asserts that the transactional reading process consists of a continuum between the efferent stance and the aesthetic stance when interacting with the literary text. The reader can determine whether adopting a predominantly aesthetic stance or a predominantly efferent stance. He/she can even experience both stances during the reading event. The reader's logic and feelings, or what Rosenblatt (2005) calls "the mind and emotions of some particular reader" (p. 32), play an important part in the construction of meaning during the reading act. Therefore, this study adopted the principles of transactional reading to be implemented in the EFL classroom so that learners could read authentic literary language, negotiate meaning, and produce critical thinking through poetry.

\section{Research methodology}

\subsection{Research type}

This is an exploratory case study that attempted to inquire in depth (Bassey, 2000) the positive or negative influence of the inclusion of poetry on the development of a group of EFL learners' language competence, that is to say, the understanding, production, and negotiation of meaning, in a Colombian setting. As suggested by Saunders Lewis, and Thornhill (2013), this exploratory case study was conducted in order to determine possible results, not intended to provide conclusive evidence or definite answers. It rather sought to reach a better understanding of the research topic and to analyze new data and new insights based on a specific research question. Data from participants' direct voices, verbal forms (Candlin \& Hall, 2002), and personal experiences with poetry, including 
their difficulties and achievements, supported this analysis. The research question leading this study was: How does poetry influence a group of EFL language competence learnerst hrough transactional readings?

\subsection{Context for the study and participants}

This research study was conducted in an EFL literature class of a Modern Language Education Program at a University in Colombia. Class was held twice a week from 9:00 to 11:00 a.m. It was a seventh semester advanced course composed of ten females and eight males whose ages ranged from 18 to 22. They had taken six previous English courses, each one consisting of 8 hours per week. They had learned English with the support of communicative textbooks and the practice of language skills (reading, listening, speaking, and writing), according to their own English level, whether basic, intermediate, or advanced. They had also learned English with adapted versions of reading materials, Internet resources, videos, movies, and grammar books. However, they had never read authentic literary texts in English, including poetry. Their English level, according to the Common European Framework of Reference for Languages (2001), was B2. They were able to understand the main ideas of complex texts, interact with appropriate degree of fluency and spontaneity, and produce oral and written discourse on a wide range of subjects.

\subsection{Data collection instruments}

To answer the research question, three data collection instruments were implemented during a pedagogical intervention (see Table 1) in the first academic term of 2016. Class was held twice a week, Monday and Wednesday, from 9:00 to 11:00 am. First, as suggested by Yin (2011), field notes (Appendix 1) were taken during all the class sessions by paraphrasing and writing short verbatim sentences of students' opinions and comments on the poems (the efferent stance). Notes on how they reacted emotionally to poetical language (aesthetic stance) were also taken.

Second, EFL learners' response papers/essays (artifacts) about the commentaries of the poems were collected. To write these response papers, participants answered questions related to the meaning of the poems during the individual transactions and after class discussions, so that they had the opportunity to write about their own personal views 
and final interpretations. Third, participants answered a questionnaire (Appendix 2) at the end of the pedagogical intervention through which they answered open-ended and closed-ended questions about their experience with poetry.

\subsection{Pedagogical intervention}

The transactional approach was implemented in a pedagogical intervention (see Table 1) based on criteria for poem selection and criteria for class development. These criteria were used as follows:

\subsubsection{Criteria for poems selection:}

The selected poems for the experience were short; as it was an appropriate length to motivate EFL learners to read and avoid feelings of frustration with longer poems (Brumfit \& Carter, 1986). Besides, the chosen poems dealt with universal human topics (Maley \& Duff, 1989) and collective values (Kramsch, 1993), and they were suitable for learners' language level (McRae, 1991), as they were mostly written with functions, structures, and discourse at the reach of $\mathrm{B} 2$ students. The poems belonged to American literature, which was the focus of study for this EFL literature course in seventh semester. For the purpose of this article, the experience with poetry as a reading task will be analyzed with six poems as indicated in Table 1.

\subsubsection{Criteria for class development:}

Students came to class without having done any previous research about the poems, since one of the purposes was that students were not influenced by literary interpretations available in the Internet or books. The teacher researcher gave students the poems at the beginning of the class and encouraged them to read, construct meaning based on the immediate reading transaction that they established at that moment with the literary texts.

The transaction approach to reading was adopted because this research project wanted to examine how these EFL learners were able to understand and respond critically to "the verbal stimuli offered by the text" (Rosenblatt, p. 28). That is why it was crucial that students were not influenced by external literary authority because their genuine personal responses to poetry were the core of the investigation. 
Table 1. Poems discussed in the pedagogical intervention, and data collection process.

\begin{tabular}{|c|c|c|c|c|}
\hline Week & Poets & Poems & Topics discussed and activities & $\begin{array}{c}\text { Data collection } \\
\text { instrument }\end{array}$ \\
\hline One & $\begin{array}{c}\text { Emily } \\
\text { Dickinson }\end{array}$ & $\begin{array}{l}\text { "Farewell" } \\
\text { "Going to } \\
\text { heaven" } \\
\text { "Some keep the } \\
\text { Sabbath going } \\
\text { to Church" }\end{array}$ & 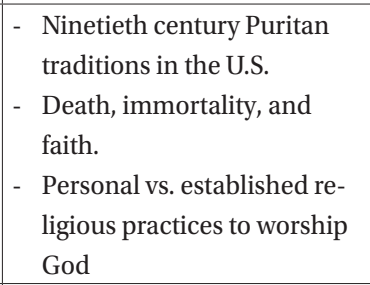 & \multirow{4}{*}{$\begin{array}{l}\text { Field notes } \\
\\
\text { artifacts } \\
\text { (short commen- } \\
\text { taries/ respon- } \\
\text { ses/ essays) }\end{array}$} \\
\hline Two & $\begin{array}{c}\text { Walt } \\
\text { Whitman }\end{array}$ & $\begin{array}{l}\text { Passages from } \\
\text { "Song of } \\
\text { Myself" } \\
\text { "When I Heard } \\
\text { the Learn'd } \\
\text { Astronomer" }\end{array}$ & 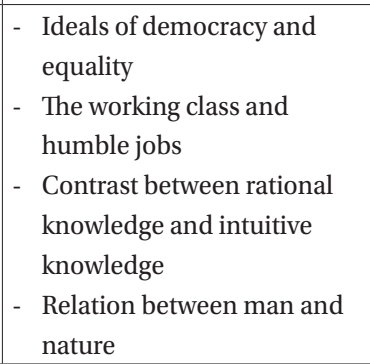 & \\
\hline Three & $\begin{array}{l}\text { Gwendolyn } \\
\text { Brooks }\end{array}$ & $\begin{array}{c}\text { "The } \\
\text { Sonnet-Ballad" }\end{array}$ & $\begin{array}{l}\text { - The effects of war on ma- } \\
\text { rried women. } \\
\text { - A married woman confron- } \\
\text { ting her husband's death. }\end{array}$ & \\
\hline Four & & $\begin{array}{c}\text { Written } \\
\text { responses/ } \\
\text { essays } \\
\text { on the poems } \\
\text { (student } \\
\text { artifacts) }\end{array}$ & $\begin{array}{l}\text { Students wrote critical com- } \\
\text { mentaries about the poems. }\end{array}$ & \\
\hline Five & Review & & $\begin{array}{l}\text { Students answered questions } \\
\text { about their experience with } \\
\text { poetry. }\end{array}$ & Questionnaire \\
\hline
\end{tabular}

Source: prepared by the author.

However, since this was the first time these EFL learners were reading poetry in English and had no idea who the poets were, the teacherresearcher provided learners with reading comprehension activities to lead the reading transactional process in three stages:

\subsubsection{Getting prepared to reading poetry}

Participants were provided with general information about the historical context, the life of the poets, and their aesthetic contributions to literature before actually reading the poems. As a warm-up activity, the teacher mo- 
tivated learners to discuss topics related to the poems, so that they could start establishing connections between their previous knowledge and experiences with the themes in the poems. For instance, before learners started to read the poems "Farewell" and "Going to Heaven"(Dickinson, 1961) whose main topics are death and immortality; the teacher asked learners the questions: "What is your personal opinion about death? Do you have a positive/negative view of death?" These first reflections were meant to help learners to compare their personal views of death to those they later found in the poems.

\subsubsection{Doing transactional reading at an individual basis}

Participants were encouraged to read the poems individually in class time. They worked with study guides containing key reading comprehension questions to focus on important details (recurrent ideas, images, symbols). Then, students started to analyze and infer specific information by doing a careful reading, in such a way that they were able to construct meaning and reach levels of interpretations. Students used their bilingual dictionaries pretty often and paid attention to lexical and linguistic structures in the poems. The individual reading was based on Rosenblatt's (1995) claim that the teachers should foster productive transactions between individual readers and individual literary works. This is so because it is important" to see the reading act as an event involving a particular individual and a particular text, happening at a particular time, under particular circumstances, in a particular social and cultural setting" (p. 100). Also, learners wrote individual responses/ commentaries about the poems to later share them with their classmates. Although this stage implied a personal and individual transaction, the teacher assisted students to provide any kind of help if needed. At the end, students shared their initial understanding of ideas, images, and meanings drawn out from the poems.

\subsubsection{Doing transactional reading at a group level}

Since Rosenblatt (1985) indicates that the literary work, like language itself, is a social product, learners worked in small groups to establish social transactions with their classmates to compare, complement, and enrich their individual analysis. Then, the whole class discussed the meanings of the poems by supporting their critical analyses with evidence. Although at the beginning of the experience, learners were nervous about sharing 
their ideas with their classmates, they increasingly engaged in critical literary analysis, as will be seen later in the findings. These social transactions enabled learners to evoke multiple meanings and reflect critically on the literary material in groups. The teacher was there to coordinate this stage. This teaching practice resonated Rosenblatt's (1995) assertion that the literary transaction should be a self-liberating process through which the reader not only has "the chance to follow his own personal bent," but "the chance to share and compare literary reactions" with other students (p. 66). It is important to clarify that the notion of transaction in this stage should not be confused with interaction. Interaction deals with communication that serves the purpose of successful communication such as respecting turns to speak cordially, paying attention to what the others are saying, using appropriate casual or formal language depending on the occasion, and asking for clarification and repetition (Richards, 2014). On the other hand, transactions, as understood by Rosenblatt, takes place when the reading purpose focuses on giving, receiving, and constructing meaning, knowledge, and information. Transaction occurs when meaningful messages or new knowledge are constructed between the reader and the literary text. Moreover, during this stage learners used social interactional skills to compare and share with other learners their personal interpretations and transactions with the poems.

\section{Data analysis}

Field notes were first analyzed based on the grounded approach (Charmaz, 2012), which is a method that helps to find patterns from the collected data in order to answer research questions. Data was read many times until recurring patterns related to how poetry influenced on participants' learning process emerged. Participants' similar opinions and reactions about the poems led to establish major relations in the data which were considered initial findings. Then, a process of triangulation (Freeman, 1998) was made with students' artifacts (written essays and responses) and the questionnaire. These instruments were analyzed systematically through content analysis, a method for reading and studying textual information, identifying its properties, and assigning similar codes or patterns (Dawson, 2002). Data triangulation confirmed similar patterns in all the instruments and made them reliable and consistent. After this process, final findings emerged which were 
shaped into statements. For example, it was detected in the field notes that participants had to look up new words in the dictionary because the poems were difficult to read.

\section{Findings}

\subsection{Poetical language encouraged EFL learners to focus on the literal and metaphorical meaning of new words}

According to data, all the 18 learners reported that reading poetry in the language classroom was a difficult task because the poems contained a great amount of vocabulary that they had never used before as language learners. This can be seen in these comments ${ }^{1}$ taken from the questionnaire (March 30):

"The most difficult part was the vocabulary because there were some words very strange or complex that are not used frequently."

"Some words are not commonly used in real life."

"In the poems, there are a lot of unknown words to us."

Participants argued that the poems contained vocabulary and linguistic structures that were not part of daily speech. Therefore, at the beginning of the experience, the reading transactions were complicated as learners made a great effort to understand the language before actually doing any meaning transactions. This finding is consistent with the field notes as it was observed that these EFL learners had to look up words in the dictionary very often to understand the literal meaning of those unknown words in the particular contexts of the poems. For instance, when learners were reading "Going to Heaven" (Dickinson, 1961), they had problems with the words "a bit of crown," in the verses "The smallest robe will fit me/And just a bit of crown," as well as with the words "as flocks," in the line "And yet it will be done as sure as flocks go home at night" (p. 79). Thus, the dictionary became a useful tool during the reading process as it was observed that the 18 learners would have not understood the poems without its support.

1 These are verbatim samples of students' production during the research experience. Therefore, some of them include grammar/language mistakes, since they were still in the process of learning English as a foreign language. 
Participants commented that because they were advanced EFL learners, they were surprised that they had to use the dictionary that often to understand the language in the poems (Field notes, February 24). One significant reason that made these EFL advanced learners depend on the dictionary was that this was the first time in their lives they were reading authentic literary language, which contrasted with the standardized forms of language that they had studied and practiced in textbooks and other reading materials in previous English courses. This finding revealed that learners were not able to make literary reading transactions immediately despite the use of study guides and questions provided for comprehension. At the beginning, they seemed to be more concerned about understanding the literal meaning of new vocabulary and analyzing the functions of those words in the poems, than addressing literary reading instantaneously.

The difficulty with language appeared to emerge from the fact that it was essentially figurative, since, learners not only found unknown words in the poems, but also, those unknown words had been used by the poets to create metaphors and similes. Hence, learners made a two-fold effort: First, to understand the literal meaning of those terms, and then to make sense of their figurative/metaphorical meaning as was observed in the aforementioned examples. Once learners understood the literal meaning, they started to figure out the metaphorical meaning of words and, eventually they managed to embark on literary reading transactions. Such was the case with "the smallest robe" in the context of the poem "Going to Heaven" (Dickinson, 1961) as learners reported that, for them, those words represented "modest clothing", suggesting that, for the speaker in the poem, "material things and stylish looks were not important to go to heaven" because she/ he "was entirely happy about leaving this material world" (Student artifact, February 24). Likewise, learners inferred that in the verse, "And yet it will be done as sure as flocks go home at night", that the poet had created a simile to compare the speaker's faith in going to heaven to the flocks that arrive home at night. For learners, "the flocks" represented "saved believers," the "night" suggested death, and "home" represented heaven (Field notes, March 22). Sixteen opinions in the questionnaires (March 30) revealed this two-fold effort with language deviation during the reading process:

"It was difficult to understand the poems when they had a lot of metaphors. It was hard to recognize the real intention of the authors." 
"The most challenging part was turning the literal meaning of words into possible interpretations."

"Given the ambiguity that comes within a poem, it was difficult to know if the interpretation was correct."

Language deviation from the linguistic norms challenged learners to make sense of those words in the poems which incorporated a different connotation from the common meaning explained in the dictionary. No surprise, then, this process was slow and hard to accomplish. Eventually, learners were capable of inducing logical meaning out of such figurative language through their carefully transactional analysis. This task turned out to be a demanding experience as they first needed to understand language structures and vocabulary and then figure out their poetical meaning. Despite this tough experience with poetical language at the beginning of this experience, learners realized that they were not only working with authentic language, but were also understanding and constructing meaning during the reading act, this being an instance of a communicative reading task in the EFL class.

\subsection{Poetical language helped EFL learners enhance language competence and critical reading}

Even though participants complained about the unknown vocabulary and metaphorical properties of the poems, data indicated that all of them gradually recognized that poetry was an excellent resource to improve their English competence. 13 students reported that poems helped them to learn vocabulary in context, while 15 students affirmed that they had enhanced their language skills. This could be seen in some comments and replies in the questionnaires (March 30):

"The poems helped me to learn new vocabulary."

"What I have improved the most thanks to the poems are my speaking and reading skills, because if you speak, even if you make mistakes, your fluency will improve. Also, if you read, even if you don't understand, you are going to get accustomed to read poetry anyway."

"I consider that the analysis of the poems helped me to improve my reading process and vocabulary." 
"With poetry, you learn to read in a critical way. You improve your language skills."

10 participants out of 18 stated that reading transactions had allowed them to be better readers. In fact, their reading skills appeared to develop sequentially as they read word by word and stanza by stanza in order to figure out the main ideas of the poems. That was the case with the poem "The Sonnet-Ballad" (Brooks, 1975) when students were requested to discuss the central ideas based on a list of reading comprehension questions provided by the teacher. After students completed the individual reading transaction, they discussed the poem with the whole class. It was observed that during the discussion they used the foreign language to exchange important ideas and elements in the poem, mainly the possible meaning of the image "empty heart-cup" in the verses "Now I cannot guess what I can use an empty heart-cup for/ He won't be coming back here anymore" (Brooks 1975). Some of the learners compared the heart of the female voice in the poem to an empty cup "not having coffee" (Field notes, March 7). In this sense, some learners said that "the 'empty heart-cup' suggested that the woman felt lonely because her husband had died and she would not see him anymore" (Field notes, March 7). Other students said that the empty heart-cup suggested "the loss of love" because once her husband had been killed in the war "she could not experience love anymore" and "she would have a lonely life with no sense" (Field notes, March 7).

Another case of literary transaction was made when two students said that they liked the verses "That my sweet love .../Would have to court coquettish death, whose impudent and strange/ Possessive arms and beauty (of a sort)/ Can make a hard man hesitate and change" (Brooks, 1975). They said that in these lines "Gwendolyn Brooks has used the personification of death" because "death was described with female characteristics," being "coquettish, possessive, and beautiful," and that they had associated this description with a flirtatious and seductive woman who "had stolen the married woman's husband in the war"(Field notes, March 7). These opinions led the whole class, with the help of the teacher, to explain the meaning of personification in literature, and discus show the married woman (the voice in the poem) metaphorically described death as a femme fatale who had trapped her husband in the war, this being an unconventional way that Brooks, the poet, described death in the poem. The discussion of "The Sonnet-Ballad" on universal topics such 
as love, death, and the negative effects of the war on married women led these EFL learners into developing critical reading skills and the efferent stance (Rosenblatt, 2005), since the reading transactions allowed them to develop argumentative competence by considering the discussion and interpretation of literary language.

Critical analysis was also produced when learners read “When I Hear'd the Learned Astronomer"(Whitman, 2006) asthey shared and expressed interesting opinions, namely that the "astronomer" represented scientists, that the "charts" and the "graphs" represented science or math. Some of them even claimed that "the speaker didn't like science class because graphs and figures were boring," and that "the speaker prefers to go out the lecture room and enjoy nature"(Field notes, February 2). These enthralling ideas about Whitman's poem were the result of their personal reading transactions, being intellectually activated by "the verbal stimuli offered by the text"(Rosenblatt, p. 28). At the end of the discussion, students concluded that the poet wanted to establish the difference between scientific knowledge and experiential/personal knowledge, and that the poet valued more intuitive knowledge, represented by the words "mystical moist," "the perfect silence," and "the stars," than scientific knowledge represented by the "astronomer" and his "figures and graphs" (Filed notes, February 2).

These findings evidenced that students were able to construct meaning through their transactional relations with the poem. Moreover, they made interpretations of this poem in the foreign language, reading it without the influence of literary authorities. Likewise, these data showed that learners improved lexical competence as well as reading and speaking skills through poetry, fundamental aspects of communicative competence. Also, there was evidence of efferent reading as it was observed that learners examined, reflected upon, and analyzed information/content, and implied meaning based on rational interpretations supported by evidence, as suggested by the transactional theory. It is crucial to mention that these learners were not expected to do professional literary analysis, but rather to construct meaning when reading the materials. However, many of the ideas and meanings they found in the poems displayed traits of literary analysis.

Language competence and critical argumentation were also developed when learners were requested to answer the question: What is the main theme in the poem? after reading either one of two poems in one 
class session: "Some keep the Sabbath going to church" (Dickinson, 1961) and "I Hear America Singing" (Whitman, 2006). Learners had the whole class session (March 14) to embark on the individual reading transaction and write a free response on the theme of the poems:

In the poem "I Hear America Singing," the speaker expresses a sense of unification and cooperation among American workers with the words "America Singing." The main idea the speaker develops is that workers of America, mechanics, hatters, and boatmen, "sing together" because they are proud of their jobs; they are happy because they are aware of the importance of their jobs for the contribution to American society (student artifact, March 14).

In the poem "Some keep the Sabbath going to Church," [...] the speaker feels her home as a church where she can find God. She prefers to enjoy the sound of a bobolink and see her orchard; these natural resources make her feel the presence of God in her own home. [...] She says "So instead of getting to heaven at last, I'm going all along" (third stanza). For her, another way of searching God is to live every single day enjoying the beauty of the nature... (student artifact, March 14).

These data illustrate how EFL learners were able to produce logically connected arguments to defend their personal critical interpretations of the poems, which suggested they had engaged in efferent reading. They developed critical arguments with sufficient evidence and coherent logical flow as they analyzed relevant words, images, and verses in the poems. In the case of the first sample, the student deduced from the context in the poem that the words "America Singing" referred to all the workers of the U.S. being happy, proud of, and cooperative with the economic progress of their country. In the second sample, the student interpreted that the words "orchard" and "bobolink" represented for the speaker in the poem sacred elements innature through which he/ shewas able to connect with God, without having to go to a conventional church.

This interpretative and critical production was the result of mutual transactions between these particular readers and the literary texts, as explained by Rosenblatt (2005). Thus, in the first sample, the student contended the idea that Whitman emphasized the importance of the work- 
ing class in the development of America as a nation, while in the second sample, the student argued that the speaker in the poem experienced God through nature. These findings seemed to confirm the idea that poetry was a useful resource to foster critical reading and argumentation in EFL, as has been proposed by Kramsch (1993), Hismanoglu (2005), and Khansir (2012).

One revealing finding is that EFL learners produced critical opinions about the poems because they engaged in close reading. Close reading takes place when readers embark on a detailed examination of literary passages by drawing careful attention to the words, grammar, and the order in which the sentences are arranged in order to make logical inferences from language and finally construct meaning. According to Culler (1997), close reading helps readers to "produce richer, more insightful interpretations of individual work" (p. 122). Hence, it was observed that the participants of this study were concerned about understanding all the words and scrutinizing how those words were related to other language features in the poems. They examined word by word and read the poems several times to make sense of the linguistic structures. They not only constructed meaning out of the different language elements in the poems, but also produced critical arguments to defend their interpretations. The fact that these EFL learners implemented close reading indicated that they adopted a predominant efferent stance rather than a predominant aesthetic stance, precisely because they were interested in understanding how language forms worked in the poems in order to grasp a logical and coherent level of meaning construction.

\subsection{Learners affirmed that beingen couraged to infer figura- tive language in the poems was apleasant learning experience}

Although most of the data analysis revealed that learners regarded these poems as difficult because of their complex language and literary ambiguity, all of them, except one, asserted that they had enjoyed reading the poems because of several aesthetic reasons. To the question in the questionnaire, "Did you like/dislike the poems? Explain your answer", four learners said that they enjoyed the poems because of their literary beauty, while three learners valued how the poems evoked good feelings and depicted interesting human universal topics:

I really liked them, especially because they were connected to profound human mysteries such as death and God. 
I loved all of them because they reflect different personal emotions, such as love and passion, and I got exited while reading them.

I liked how Gwendolyn Brooks describes death as a flirtatious beautiful woman. I also felt pity for the married woman who was heartbroken for her dead husband in the war.

Recurrent words in the data such as "I really liked," "I loved," and "I felt," clearly portrayed the aesthetic stance that readers experienced during the reading transaction. They admitted having responded emotionally through feelings of joy, pleasure, pain, and sadness when they said that they had developed aesthetic sensibility to poetical structure and figurative language in class discussions. For instance, learners commented that the poem "Farewell" (Dickinson, 1961) included a beautiful metaphor in which death was compared to an "eternal trip on horses" or to a "carriage pulled by horses" (Field notes, February 22) in the verses: “Then I am ready to go!/Just a look at the horses-Rapid! That will do!" (Dickinson, p. 279). Similarly, aesthetic pleasure was detected when learners discussed "Song of my Self" (Whitman, 2006) specifically with the verse "The pleasures of heaven are with me, and the pains of hell are with me" (p. 24). For the learners, "pleasures of heaven" and "pains of hell" were beautiful figurative language through which "the poet recognizes that his human condition is defined by a good and a sinful side" (Verbatim data, field notes, February 30).

Learners' comments on how they were able to experience human emotions through the beauty of images, symbols, and other figurative language, indicated how they were moved by esthetic stances during the reading continuum. Rosenblatt's (1995) theory indicates that this happens when "the reader's attention is centered directly on what he is living through during his relationship with that particular text" (p. 25). In other words, reading poetry not only helped learners to build knowledge, communicative competence, and critical reading, but to appreciate the beauty of literary language in the foreign language. Moreover, the EFL classroom was a space to talk about human feelings, personal values, and human experiences.

\subsection{Limitations of the study and further research}

Since this was an exploratory case study research, counting on a small amount of data and participants, the findings can only be understood 
within its setting in a classroom in Colombia. Therefore, further research needs to be done with a greater amount of data in other Colombian Language Education Programs and EFL classes in high schools and primary schools. For instance, the effects of children's and teenagers' poetry on young readers' lexical competence, pronunciation, and reading comprehension, among other language aspects, still need to be approached. There is the need to encourage teachers and English learners to see poetry as an authentic reading task that can help them become aware of language features and construct meaning, instead of seeing poetry as a tough and problematic material in language learning.

\section{Conclusions}

This exploratory case study has shown that integrating poetry in an EFL classroom in Colombia influenced students' language competence in positive ways. According to the findings, poetry enhanced their lexis, as learning vocabulary was a constant practice in class. This project helped them develop the ability to understand unknown words in meaningful literary contexts, instead of learning lists of words and grammar structures in isolation as it still happens in EFL classrooms. Also, based on students' opinions, this study concludes that poetry was a powerful material to improve the four language skills (reading, listening, speaking, and writing), because it enabled learners to be critical readers and better speakers and writers to develop arguments based on evidence.

This study concludes that the transactional approach should be implemented in EFL education, so that learners can be involved in efferent and aesthetic stances during reading tasks. This approach can lead them into analyzing and interpreting meaning, as well as into enjoying the aesthetic beauty of literature. EFL teachers should, then, take advantage of the power of language ambiguity in poetry so that they and students mutually help each other to negotiate meaning and consider diverse interpretations based on logical reasoning and evidence.

In addition, the findings of this study appear to indicate that poetry needs to be regarded as authentic language material that can complement other conventional instructional resources such as textbooks, videos, and grammar books. Appropriate selection of poetry, according to learners' own English language level, without pressure and preconceptions, can result in an enriching content-based experience and in a meaningful 
communicative process, as learners discuss poetry based on responsible reading and enjoyment.

As suggested by the findings, Colombian learners changed their minds about the widespread idea that poetry was unsuitable for their EFL learning. As could be seen, despite the challenges they encountered with ambiguous verses and stanzas and with unknown words, they enjoyed poetry and gave positive comments about its inclusion in language learning, since they managed to understand that reading and talking about poetry can also be one of the many authentic communicative tasks that people do and enjoy in real life. Consequently, this literary genre should not only be a part of teaching materials in other EFL educational contexts worldwide but should continue being a research agenda in second/foreign language learning.

\section{References}

Bassey, M. (2000). Case study research in educational settings. Philadelphia: Open University.

Bernhardt, E. (2001). Research into the teaching of literature in a second language: What it says and how to communicate it to graduate students. SLA and the Literature Classroom, 27, 2001, 195-210. Retrieve from: http://files.eric.ed.gov/fulltext/ED481420.pdf

Brumfit, Christopher and Carter, R. (1986). Literature and language teaching. Cambridge: Cambridge University Press.

Brooks, G. (1975). The Sonnet-Ballad. English for Today: Book Six Literature in English. Ed. W. Slager \& W. Davis. New York: McGraw-Hill Book Company.

Buckledee, S. (2002). Language and literature in tertiary education: The case for stylistics. English Teaching Forum, 4o(2), 8-13. ERIC Number: EJ671634.

Charmaz, K. (2012). The power and potential of grounded theory. Medical Sociology Online. 6(3), 2012, 1-15. Retrieved from:http://www. medicalsociologyonline.org/resources/Vol6Iss3/MSo-6oox_ The-Power-and-Potential-Grounded-Theory_Charmaz.pdf

Canale, M. (1993). From communicative competence to communicative language pedagogy. In Richards, J. C., \& Schmidt, R. W. (Eds.), Language and Communication (pp. 2-27). London: Longman. 
Candlin, C. (2002). David Hall, and Joan Hall. Teaching and researching: Language and culture. Esses, England: Longman.

Clapsadle, Carter L. (2014). Poetic Research in the Second Language Classroom Unpublished master's thesis, St. Cloud State University, Cloud, MN.

Conway, N. (2015). Developing student responses to poetry in English: Guided reader response in EAP reading classes. 小金井論集, 11(9), 71-84. Retrieved from: http://ci.nii.ac.jp/naid/120005671328

Culler, J. (1997). Literary theory: A very short introduction. Oxford: Oxford University Press.

Dickinson, E. (1961). The complete poems of Emily Dickinson. Boston: Back Bay Books.

Dawson, C. (2002). Practical research methods: A user-friendly guide to mastering research techniques and projects. Oxford: Howtobooks.

Freeman, D. (1998). Doing teacher-research: From inquiry to understanding. Boston: Heinle and Heinle.

Hanauer, D. (2001). The task of poetry reading and second language learning. Applied Linguistics, 22(33), 295-323. doi: 10.1093/ applin/22.3.295

(2010). Poetry as research: Exploring second language poetry writing. Amsterdam: John Benjamins Publishing.

Kellem, H. (2009). The formeaning response approach: Poetry in the EFL classroom. English Teaching Forum, (4), 12-17. Retrieved from http://files.eric.ed.gov/fulltext/EJ923461.pdf

Khansir, A. (2012). Teaching poetry in the EFL classroom. International Review of Social Sciences and Humanities, 3(1), 241-245. Retrieved from: http://irssh.com/yahoo_site_admin/assets/ docs/24_IRSSH-288-V3N1.131231639.pdf

Khatib, M. (2011). A new approach to teaching English poetry to EFL students. Journal of Language Teaching and Research, 3(1), 164-169.

Retrieve from: http://connection.ebscohost.com/c/articles/63889542/new-approach-teaching-english-poetry-eflstudents 
Kramsch, C. (1993). Context and culture in language teaching. Oxford: Oxford University Press.

Lazar, G. (1993). Literature and language teaching. Cambridge: Cambridge University Press.

McRae, J. (1991). Literature with a small ' $l$ '. London: McMillan Publishers.

Maley, A. (2001). Literature in the language classroom. In Roland Carter and David Nunan (Eds.) The Cambridge guide to teaching English to speakers of other languages (pp. 180-185). Cambridge: Cambridge University Press.

Maley, A. \& Duff, A. (1989). The inward ear: Poetry in the language classroom. Cambridge: CUP.

McKay, S. (1982). Literature in the ESL classroom. Tesol Quarterly, 16(4), 529-539. doi: 10.27/3586470

Panavelil, A. (2011). Teaching poetry in an EFL/ESL Class: An integrative and communicative approach. ELT Voices India Journal, 1(3), 11-20. Retrieved from: eltvoices.in/Volume1/Issue3/EVI13.2.pdf

Paran, A. (2006). The stories of literature and language teaching. In Amos Paran (Ed.). Literature in Language Teaching and Learning (pp. 11-26). Washington: Case Studies in Tesol Practice Series.

Prather, K. (2001). Literature-based exploration: Efferent and aesthetic. (Unpublished master's thesis). Educational Resources Information Center. California, Dominican University of California.

Probst, R. (1988). Transactional theory in the teaching of literature. ERIC Clearinghouse on Reading and Communication Skills, 31(4), 378-381. ERIC Identifier: ED284274.

Richards, J. (2014). Teaching speaking for interactional versus transactional purposes. The official website of educator \& arts patron Jack C Richards. Retrieved from: http://www.professorjackrichards.com/

Richards, J. \& Rodgers, T. (2001). Approaches and methods in language teaching ( $2^{\text {nd }}$ ed.). Cambridge: Cambridge University Press.

Rosenblatt, L. (2002). La literatura como exploración. México: Fondo de Cultura Económica.

(1995). Literature as exploration ( $5^{\text {th }}$ ed.). New York: The Modern Language Associations of America. 
Sakamoto, K. (2015). Translation of Japanese poems into English: Literature in the first language as a motive to communicate in a second language. In. M. Teranishi, Y. Saito, and K. Wales, Literature and language learning in the EFL classroom (pp. 197211). New York: Palgrave Macmillan.

Savignon, S. (1972). Communicative Competence: An Experiment in Foreign LanguageTeaching. Philadelphia: The Centre for Curriculum Development, Inc.

(2001). Communicative language teaching for the twenty first century. In M. Murcia (Ed.), Teaching English as a Second/Foreign Language (pp. 12-28). Boston, MA: Heinle \& Heinle.

Starz, M. (1995). Communicating through poetry in an ESL classroom. Texas Papers in Foreign Language Education, 2(1), pp. 3-14.

Saunders, M., Lewis, P. \& Thornhill, A. (2013). Research Methods for Business Students ( $6^{\text {th }}$ ed.). New York: Pearson Custom Publishing.

Qiping, Y. and Shubo, C. (2002). Teaching English literature in china: importance, problems, and counter-measures. World Englishes, 21(2), 317-324 doi: 10.1111/1467-971X.00251

Widdowson, H. G. (1984). Explorations in applied linguistics. Oxford: Oxford University Press.

Whitman, Walt. (2006). The Complete poems of Walt Whitman. London: Worthsword Poetry Library.

Yin, R. (2003). Case study research: Design and methods. USA: Sage Publications, 2003. 


\section{Appendix 1}

Data collection instrument: Observation sheet (field notes)

Research Question:

How does poetry influence the development of language competence of a group of EFL learners through transactional readings?

Classroom_ Date:

Poem read: Author:

Activity:

Observations (field notes) Researcher's Comments 


\section{Appendix 2}

\section{Questionnaire about the poems studied in class}

After finishing the section on poetry, please answer the following questions sincerely.

1. What did you learn with the poems discussed in class?

2. What was easy about reading the poems?

3. What was difficult about reading the poems?

4. Did the poems help you in any way to improve L2 learning? Yes _ No_ Why?

5. Did you like/dislike the poems? Explain your answers.

Thank you! 